Diabetologia 11, 237-239 (1975)

(c) by Springer-Verlag 1975

\title{
Early Insulin Release and Its Response to Potassium Supplementation in Protein-Calorie Malnutrition
}

\author{
D. J. Becker, M. D. Mann, E. Weinkove and B. L. Pimstone \\ Departments of Medicine and Child Health, University of Cape Town, South Africa \\ Received: October 17, 1974, and in revised form: April 8, 1975
}

\begin{abstract}
Summary. Early insulin release after oral glucose is absent in protein-calorie malnutrition (PCM). There is an increase of the insulin-glucose ratio at 10 and $15 \mathrm{~min}$ induced by potassium supplementation compared to a similar group receiving an identical diet without supplementary potassium. This suggests that impaired insulin secretion in PCM is in
\end{abstract}

part due to a potassium mediated disturbance of insulin release. tion.

Key words: Insulin, potassium, protein-calorie malnutri-

excluded but one child (Patient 5) developed severe pneumonia 3 days after admission. Informed written consent was obtained from a parent of each patient.

After an $8 \mathrm{hr}$ overnight fast on the second hospital day, (day 1 being the day of admission), an oral glucose load ( $2 \mathrm{~g} / \mathrm{kg}$ as a $20 \%$ solution) was administered via nasogastric tube over $2 \mathrm{~min}$. Venous blood samples $(1 \mathrm{ml})$ were taken at $0,5,10,15,30$ and $60 \mathrm{~min}$ for glucose and insulin estimations. Alternate patients, i.e. 5 of the 10 , selected randomly, received oral potassium supplements $(12 \mathrm{mEq} / \mathrm{kg} /$ day $)$, while the remainder received potassium $(3 \mathrm{mEq} / \mathrm{kg} /$ day $)$ as part of the conventional management.

The test was repeated on the 5th hospital day in both the supplemented and non-supplemented patients, after which all patients were given potassium supplements for a further week. A final test was done 3-5 weeks from admission when the children had recovered clinically and serum albumin levels had returned to normal.

Micro assays were employed for the estimations of blood glucose by a glucose oxidase method [11] and for plasma insulin by a modification of the Morgan and Lazarow technique [11]. Insulin-glucose ratios were calculated at each point in time before and after glucose. After plotting the absolute insulin values before and after glucose on arithmetic paper, the total insulin area above baseline was calculated by planimetry. The Mann-Whitney U test was used to estimate differences between the groups, and the Wilcoxon test for with group differences.

\section{Results}

On admission there was no significant difference $(p>0.02)$ between the two groups with respect to age (18 vs 16 months), serum albumin (1.72 vs 2.08 with overt infection or severe gastroenteritis were 
$\mathrm{g} / 100 \mathrm{ml}$ ), insulin area (Table 1) or insulin-glucose ratio (Fig. 1).

Insulin-glucose ratios during the first $30 \mathrm{~min}$ after glucose loading failed to rise in all patients on admission, whereas on recovery, the ratios were substantially elevated at all times in both groups.

On day 5 , after 3 days of protein feeding and potas-

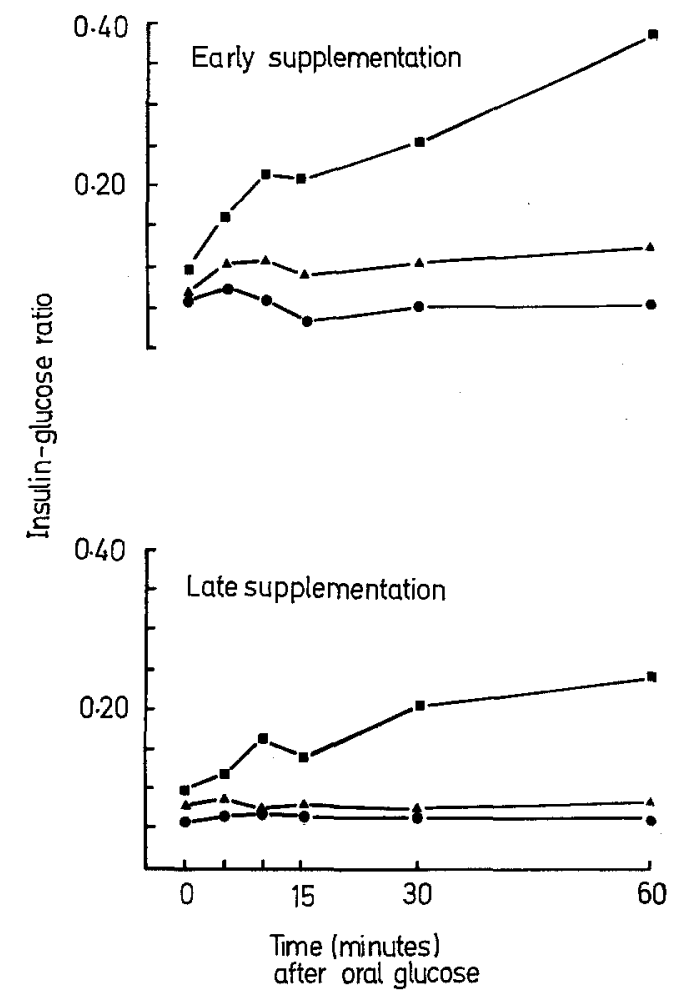

Fig. 1. Insulin-glucose ratios before and after oral glucose in 2 groups of 5 children with protein-calorie malnutrition. One group (early supplementation) received potassium $12 \mathrm{mEq} /$ $\mathrm{kg}$ /day for the first 3 days, while the other (late supplementation) received $3 \mathrm{mEq} / \mathrm{kg} /$ day during the same period. In each group, insulin-glucose ratios are shown on the day after admission, i.e. day $2(-)$, on day $5(\boldsymbol{\Delta}-\boldsymbol{\Delta})$ and on discharge 3-5 weeks later (- There is an increase in insulin-glucose ratio on day 5 in the early potassium supplemented group only, achieving statistical significance at 10 and 15 minutes $(p<0.05)$. Both groups show substantial and highly significant increase $(p<0.005)$ on discharge)

sium $3 \mathrm{mEq} / \mathrm{kg} / \mathrm{day}$, no significant increases of the insulin-glucose ratios or the insulin area were found. By contrast, 3 of 5 potassium supplemented $(12 \mathrm{mEq} /$ $\mathrm{kg} /$ day) children showed a substantial increase in early $(5,10,15 \mathrm{~min})$ insulin responses to glucose on day 5 , a further patient had a modest increase, while the fifth child showed no improvement, but developed severe pneumonia at the time. Insulin-glucose ratios in the group as a whole were increased at all time intervals after glucose, achieving statistical significance $(p<0.05)$ at 10 and $15 \mathrm{~min}$. The increase in insulin area between days 2 and 5 was significantly greater in the potassium supplemented group $(p<$ $0.05)$.

After 3-5 weeks of refeeding the responses were greater in the early potassium supplemented group so that their insulin areas were also significantly higher $(p<0.05)$.

Table 1. Insulin area (see text) in 5 children with PCM supplemented with potassium from day 2, and in 5 not supplemented until day 5 of hospital admission. In the early potassium supplemented group, insulin area is significantly increased by day $5(p<0.05)$ whereas no significant change is found in the non-supplemented group by day 5. On discharge, both groups showed significant increases in insulin compared to day $5(p<0.005)$. The insulin area on discharge in the group supplemented from day 2 is significantly higher than the group supplemented only after day $5(p<0.05)$

\begin{tabular}{clll}
\hline & \multicolumn{2}{l}{ Insulin area } & \\
\cline { 2 - 4 } & Day 2 & Day 5 & Discharge \\
\hline Patient 1 & 0.92 & 4.20 & 11.50 \\
2 & 0.83 & 2.45 & 11.41 \\
3 & 2.42 & 7.34 & 10.02 \\
4 & 0.99 & 5.18 & 6.67 \\
5 & 0 & 0.73 & 8.44 \\
\hline Mean Potassium & & & \\
Supplemented & 1.03 & 3.98 & 9.61 \\
\hline Patient6 & 0.99 & 1.55 & 5.22 \\
7 & 0.68 & 1.08 & 6.31 \\
8 & 0.07 & 1.42 & 5.66 \\
9 & 1.64 & 0.91 & 6.98 \\
10 & 0 & 2.67 & 9.84 \\
\hline Mean, Non- & & & \\
Supplemented & 0.68 & 1.53 & 6.80 \\
\hline
\end{tabular}

\section{Discussion}

Insulin secretion in response to glucose stimulation normally occurs in 2 phases both in vivo $[4,12]$ and in vitro $[13,14]$. The early phase is thought to represent release from a storage pool in the $\beta$-cells, stimulated after oral glucose both by gut $\beta$-cytotrophic factors and by the metabolism of glucose within the islet cells $[4,12]$. This early insulin response appears to be a major factor in producing normal glucose utilization and its absence could be one of many factors causing glucose intolerance. The later phase probably represents slower release from another pool which is constantly replenished by continuing insulin synthesis [12].

Our previous studies [2] have shown that in all cases of PCM there is an abnormal insulin response to oral glucose, the peak levels either being grossly diminished or delayed and sustained. However sampling of blood between 0 and 30 minutes after oral glucose was not done. 
This study shows that whereas the recovered child had an obvious IRI response 5 to $10 \mathrm{~min}$ after oral glucose, in no untreated case was there any substantial insulin rise before $30 \mathrm{~min}$. The absence of an early insulin response in these cases suggests either failure of a release mechanism at the level of the gut or $\beta$ cells, or depletion of the rapidly releasable pool by subnormal synthesis. The improvement after potassium supplementation implies a role for potassium depletion in this abnormality.

From this and previous studies [10, 16], it appears that the poor insulin secretion in PCM may be rapidly reversible in most cases. Although probably due in part to the introduction of protein feeding, the early insulin responses do not improve during initial therapy unless substantial quantities of potassium are added to the regime. Of interest and possible therapeutic relevance is the observation in this small group of patients, that introduction of potassium supplementation $a b$ initio seems to result in greater insulin recovery in some cases after $3-4$ weeks. However the significance of this observation is unclear as the number of patients studied is small, and the rates of recovery of other nutritional parameters were the same in both groups.

Acknowledgements. This study was supported by grants from the South African Medical Research Council, South African Atomic Energy Board, University of Cape Town Staff Research Fund and Wellcome Trust.

\section{References}

1. Becker, D. J., Pimstone, B. L., Hansen, J. D. L., Hendricks, S.: Insulin secretion in protein-calorie malnutrition. I. Quantitative abnormalities and response to treatment. Diabetes 20, 542-551 (1971)

2. Becker, D. J., Pimstone, B. L., Hansen, J. D. L., MacHutchon, B., Drysdale, A.: Patterns of insulin response to glucose in protein-calorie malnutrition. Amer. J. clin. Nutr. 25, $499-505$ (1972)

3. Fischer, U., Hommel, H., Ziegler, M., Michael, R.: The mechanism of insulin secretion after oral glucose administration. I. Multiphasic course of insulin mobilization after oral administration of glucose in conscious dogs.
Differences to the behaviour after intravenous administration. Diabetologia 8, 104-110 (1972)

4. Porte, D. Jr., Pupo, A. A.: Insulin responses to glucose. Evidence for a two pool system in man. J. clin. Invest. 48, $2309-2319$ (1969)

5. Grodsky, G. M., Bennet, L. L.: Cation requirements for insulin secretion in the isolated perfused pancreas. Diabetes 15, 910-913 (1966)

6. Conn, J. W.: Hypertension, the potassium ion and impaired carbohydrate tolerance. New Engl. J. Med. 273, $1135-1143$ (1965)

7. Gorden, P.: Glucose intolerance with hypokalemia. Failure of short-term potassium depletion in normal subjects to reproduce the glucose and insulin abnormalities of clinical hypokalemia. Diabetes 22, 544-551 (1973)

8. Kaess, H., Schlierf, G., Ehlers, W., von Mikulicz-Radecki, J.-G., Hassenstein, P., Walters, K., Brech, W., Hengstmann, J.: The carbohydrate metabolism of normal subjects during potassium depletion. Diabetologia 7, 82-86 (1971)

9. Hansen, J. D. L.: Electrolyte and nitrogen metabolism in kwashiorkor. S. Afr. J. Lab. clin. Med. 2, 206-231 (1956)

10. Mann, M. D., Becker, D. J., Pimstone, B. L., Hansen, J. D. L.: Potassium supplementation, serum immunoreactive insulin concentrations and glucose tolerance in proteinenergy malnutrition. Brit. J. Nutr. 33, 55-61 (1975)

11. Weinkove, C., Weinkove, E. A., Pimstone, B. L.: Micro assays for glucose and insulin. S. Afr. med. J. 48, 365-368 (1974)

12. Porte, D., Bagdade, J. D.: Human insulin secretion. An integrated approach. Ann. Rev. Med. 21, 219-240 (1970)

13. Grodsky, G. M., Bennett, L. L., Smith, D. F., Schmid, F. G.: Effect of pulse administration of glucose or glucagon on insulin secretion in vitro. Metabolism 16, 222-233 (1967)

14. Curry, D. L., Bennet, L. L., Grodsky, G. M.: Dynamics of insulin secretion by the perfused rat pancreas. Endocrinology 83, 572-584 (1968)

15. Gomez, M., Curry, D. L.: Potassium supplementation of insulin release by the perfused rat pancreas. Endocrinology 92, 1126-1134 (1973)

16. Becker, D. J., Pimstone, B. L., Hansen, J. D. L.: The relationship between insulin secretion, glucose tolerance, growth hormone and serum proteins in protein-calorie malnutrition. Pediat. Res. 9, 35-39 (1975)

Dr. B. L. Pimstone

University of Cape Town

Department of Medicine

Medical School

Observatory

Cape

South Africa 